\title{
ANALISIS KEBIJAKAN SATU DATA KALIMANTAN BARAT DI ERA PEMERINTAHAN GUBERNUR SUTARMIDJI
}

\author{
Sri Maryuni ${ }^{1}$, Sugito ${ }^{2}$, Adityo Darmawan Sudagung ${ }^{3}$ \\ 1 Program Studi Ilmu Administrasi Publik FISIP \\ Universitas Tanjungpura, Pontianak \\ 2 Program Studi Ilmu Administrasi Publik FISIP \\ Universitas Tanjungpura, Pontianak \\ 3 Program Studi Hubungan Internasional FISIP \\ Universitas Tanjungpura, Pontianak
}

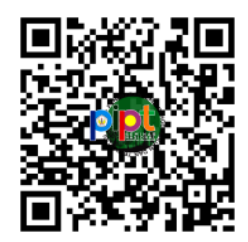

$10.26418 /$ pipt.2021.10

Email korespondensi: adityo.ds@fisip.untan.ac.id

\begin{abstract}
Abstrak
Tulisan ini bertujuan menjelaskan proses penyusunan dan implementasi kebijakan Satu Data Kalbar di era pemerintahan Gubernur Sutarmidji. Pemda Kalimantan Barat melakukan gebrakan dengan mengeluarkan kebijakan Satu Data Kalbar pada tahun 2019. Gebrakan masif ini dilakukan di era pemerintahan Sutarmidji-Ria Norsan. Penelitian ini menggunakan pendekatan kualitatif dengan mengumpulkan data dari sumber-sumber terpercaya baik melalui wawancara, observasi, dan studi dokumentasi. Setidaknya dua konsep digunakan dalam analisis penelitian ini, yaitu analisis kebijakan dan faktor kepemimpinan dalam proses penyusunan kebijakan. Peneliti menemukan bahwa upaya implementasi Satu Data Kalbar telah dilaksanakan didorong oleh keinginan dari Pemda dan sejalan dengan keinginan pemerintah pusat. Beberapa faktor penyusunan kebijakan juga ditemukan mulai dari interaksi elit, tahapan implementasi, dan monitoring. Temuan kami adalah faktor Sutarmidji sebagai pimpinan sangat signifikan. Sosok Sutarmidji sebagai pimpinan dipengaruhi oleh beberapa faktor, yaitu kepribadian, pengalaman pribadi, keluarga, lingkungan sosial dan politik di Kalimantan Barat. Hasil penelitian kami diharapkan dapat memberikan sumbangan pemikiran terhadap proses penyusunan dan implementasi kebijakan yang didukung faktor kepemimpinan di suatu rezim pemerintahan.
\end{abstract}

Kata kunci: analisis kebijakan, kepemimpinan, satu data Kalbar

\section{PENDAHULUAN}

Pemerintah Provinsi di era Sutarmidji sangat serius menangani masalah-masalah yang ada di Kalimantan Barat (Kalbar) melalui misi pembangunan berwawasan lingkungan. Pencapaian misi tersebut merupakan bagian dari visi rezim beliau, yaitu terwujudnya kesejahteraan masyarakat Kalimantan Barat melalui percepatan pembangunan infrastruktur

dan tata kelola pemerintahan yang baik (Pemerintah Provinsi Kalimantan Barat, 2019). Genjotan sangat serius beliau lakukan untuk mengatasi semua permasalahan di Kalimantan Barat dengan meluncurkan kebijakan Satu Data Kalimantan Barat. Kebijakan Satu Data Kalbar dituangkan melalui Pergub no. 119 tahun 2019.

Kebijakan Satu Data Kalbar ditujukan sebagai basis penyusunan rencana pembangunan dan merupakan bagian tak terpisahkan dari penerapan Peraturan Presiden no. 39 tahun 2019 tentang Satu Data di tingkat daerah. Selain mengeluarkan peraturan gubernur, Sutarmidji juga mengakselerasi penerapan Satu Data Kalbar dengan meluncurkan portal Satu Data Kalbar dan Data Analytic Room (DAR). Kedua instrumen menjadi gebrakan yang menarik pada zaman kepemimpinan beliau.

Sosok Sutarmidji memang menarik untuk dikaji juga dalam konteks aktor dalam perumusan kebijakan. Kiprah politik selama menduduki kursi Dewan Perwakilan Rakyat Daerah, Wakil Walikota Pontianak, dan Walikota Pontianak memberikan beliau pengalaman yang sangat mumpuni dalam memimpin 
suatu daerah. Tantangan beliau saat resmi dilantik menjadi gubernur adalah mengkomandoi provinsi dengan IPM terendah di Pulau Kalimantan dan 10 besar se-Indonesia. Kepemimpinan dan sosok beliau juga beberapa kali menjadi kontroversi dan memancing perdebatan. Pada studi kebijakan publik maupun luar negeri, faktor pemimpin merupakan salah satu faktor yang tidak bisa dikesampingkan. Kepribadian dan kemampuan memimpin akan sangat mempengaruhi pembuatan serta implementasi kebijakan domestik maupun luar negeri.

Penelitian-penelitian sebelumnya yang membahas implementasi kebijakan dan faktor kepemimpinan telah dilakukan oleh para peneliti sebelumnya. Di antaranya oleh Daraba (2015), Dedi dan Sudarmo (2019), Nazmi (2018), Ayuningtyas (2018), Febriantin (2016), Raharjo (2018), Parameswari, Legionosuko, dan Prasetyo (2019), Wardi (2020), dan Fahturrahman (2016).

Hasil penelitian Daraba (2015) menunjukkan bahwa terdapat beberapa faktor yang menentukan keberhasilan program pemberdayaan masyarakat miskin di Kecamatan Polongbangkeng Utara Kabupaten Takalar Provinsi Sulawesi Selatan, yaitu sumber daya, struktur birokrasi, komunikasi, dan disposisi (Daraba, 2015). Pada kasus lain di Kabupaten Ciamis, menurut Dedi dan Sudarmo (2019) peran monitoring sangat penting untuk memantau kualitas pelayanan kebijakan publik. Menurut mereka peran Pemerintah Daerah sangat dominan sejalan dengan tingginya tuntutan dari masyarakat serta untuk memastikan ketercapaian tujuan pemerintah memberikan layanan terbaik kepada rakyat (Dedi \& Sudarmo, 2019). Implementasi kebijakan menurut Dedi dan Sudarmo (2019) pada prinsipnya adalah cara agar sebuah kebijakan dapat mencapai tujuannya. Jika berbicara tentang implementasi kebijakan, sebenarnya fokus perhatian diarahkan pada suatu cara yang dilakukan agar suatu kebijakan dapat mewujudkan tujuannya sesuai dengan harapan. Agar sebuah kebijakan yang dikeluarkan dapat berjalan sesuai dengan tujuan, dalam pelaksanaannya harus dilakukan monitoring untuk mengukur tingkat efektivitas dan keberhasilan pelaksanaan kebijakan tersebut (Dedi \& Sudarmo, 2019).

Monitoring dilakukan dengan memperhatikan aspek kualitas pelayanan yang menjadi indikator keberhasilan suatu kebijakan yang dirasakan oleh publik. Secara garis besar ada 4 unsur pokok dalam pelayanan yang unggul, yaitu: Kecepatan, Ketepatan, Keramahan, dan Kenyamanan (Dedi \& Sudarmo, 2019). Empat fungsi pemantauan dalam analisis kebijakan, yaitu: kepatuhan, auditing, akuntansi, dan eksplanasi (Dedi \& Sudarmo, 2019). Beberapa penjelasan konseptual di atas membantu peneliti menjelaskan mengenai analisis kebijakan dan implementasi kebijakan publik. Faktor individu pemimpin akan menjadi titik tekan selanjutnya dalam analisis tulisan ini.

Faktor lain yang juga penting dalam suatu implementasi kebijakan diteliti oleh Nazmi (2018) melalui kasus kebijakan pengembangan industri alat kesehatan. Faktor koordinasi dan komunikasi menjadi penting, namun tidak kalah penting faktor sumber daya manusia SDM dan kepercayaan masyarakat atas produk yang dihasilkan akibat dari penerapan kebijakan (Nazmi, 2018).

Pada pendapat lainnya oleh Ayuningtyas (2018) menyebutkan bahwa kebijakan merupakan hasil dari interkasi para aktor dalam pemerintahan. Interkasi tersebut sarat dengan kepentingan serta alokasi sumber daya dan juga tawar menawar antar elit. Beliau menjelaskan bahwa setiap tahap penyusunan kebijakan akan susah untuk melepaskan diri dari upaya perseroangan untuk memberikan pengaruh dalam penetapan kebijakan. Bahkan kekuataan politik juga dapat memberikan warna dalam kebijakan yang diambil oleh birokrat (Ayuningtyas, 2018).

Sementara Fahturrahman (2016) menekankan hasil penelitiannya pada faktor birokrasi dalam impelementasi 
kebijakan publik. Temuan beliau menunjukkan bahwa perlu kecepatan dan ketelitian dalam menerapkan peraturan perundang-undangan yang dilakukan oleh tenaga-tenaga terdidik dan terlatih (Fahturrahman, 2016).

Penelitian oleh Febriantin (2016) memiliki kemiripan dengan tulisan yang kami sajikan karena mencuplik faktor kepemimpinan terhadap kesuksesan impelementasi kebijakan publik. Beliau mengambil studi kasus di Kabupaten Purwakarta pada masa kepemimpinan Dedi Mulyadi. Temuan beliau adalah kepemimpinan Dedi Mulyadi memegang peran penting dan juga dominan dalam memastikan pelayanan publik di daerah tersebut berjalan dengan baik (Febriantin, 2016).

Penelitian Wardi (2020) menunjukkan bahwa gaya kepemimpinan merupakan ciri yang dimiliki oleh para pemimpin baik di organisasi pemerintahan maupun di luar pemerintah. Di samping itu, gaya kepemimpinan juga dapat menggambarkan karakter yang dimilikinya (Wardi, 2020). Pemimpin yang memiliki karakter yang tegas, cepat dan responsive akan mempengaruhi sikap para bawahannya untuk menyesuaikan dengan ciri-ciri karakter tersebut (Wardi, 2020). Pada sisi yang lain, bilamana terdapat karakter pemimpin yang lemah dan lambat dalam pengambilan keputusan akan berpengaruh terhadap ketidaklancaran pelaksanaan program-program pembangunan (Wardi, 2020).

Di samping itu, penelitian oleh Raharjo (2018) juga memiliki kemiripan dalam konteks objek kajian. Beliau menyampaikan hasil penelitiannya terhadap model RAD yang terpilih menjadi salah satu metode peningkatan layanan sistem informasi kebijakan publik Indonesia pada laman website transformasi.org (Raharjo, 2018). Layanan ini menyediakan informasi kebijakan publik yang ditampilkan melalui website dengan penyesuaian tampilan pada dekstop, smartphone dan tablet PC. Hal ini juga dilakukan dalam tahap implementasi kebijakan Satu Data Kalbar yang disajikan melalui website data.kalbarprov.go.id.
Sejauh ini, beberapa penelitian menunjukkan keberhasilan suatu kebijakan. Tetapi, penelitian oleh Parameswari, Legionosuko, dan Prasetyo (2019) menemukan bahwa implementasi suatu kebijakan juga dapat berdampak negatif. Hal ini ketika keterwakilan suara pemangku kepentingan tidak diakomodir dengan baik. Contohnya dalam kasus yang mereka bahas Perppu nomor 2 tahun 2017 tidak mampu memfasilitasi permasalahan aspek keormasan. Hasil temuan mereka justru kebijakan Perppu nomor 2 tahun 2017 memberikan ancaman bagi pemerintah dengan aktifitas pemberontakan akibat ketidakpuasan atas kebijakan yang dihasilkan (Parameswari et al., 2019).

Model yang menyampaikan tentang faktor-faktor yang mempengaruhi perilaku politik individu aktor politik yang merupakan kombinasi ketiga pendekatan tersebut (Ayuningtyas, 2018): 1) lingkungan sosial politik tak langsung, seperti sistem politik, sistem ekonomi, sistem budaya, dan media massa; 2) lingkungan sosial politik langsung yang mempengaruhi dan membentuk kepribadian aktor, seperti keluarga, agama, sekolah, dan kelompok pergaulan; 3) struktur kepribadian yang tercermin dalam sikap individu; 4). Faktor lingkungan sosial politik langsung berupa situasi yaitu keadaan yang mempengaruhi aktor secara langsung ketika hendak melakukan suatu kegiatan, seperti cuaca, keadaan keluarga, keadaan ruang, kehadiran orang lain, suasana kelompok, dan ancaman dengan segala bentuknya. Faktor kepemimpinan dan yang mempengaruhinya akan menjadi salah satu alat analisis kami dalam menjelaskan gaya kepemimpinan dan sosok Sutarmidji.

Tulisan ini akan berkontribusi dalam menjelaskan langkah-langkah penyusunan dan implementasi kebijakan dengan mempertimbangkan beberapa faktor, seperti faktor internal dan eksternal pemerintahan serta faktor pemimpin. Kajian tentang Satu Data Kalbar masih sangat minim dalam konteks akademik, sehingga dapat menjadi pembeda dengan 
tulisan-tulisan sebelumnya yang kebanyakan membahas aspek kebijakan di sektor-sektor lain di pemerintahan daerah khususnya Kalimantan Barat. Kajian tentang kepemimpinan Sutarmidji sebagai Gubernur Kalimantan Barat juga menjadi menarik untuk dibahas mengingat selama ini lebih banyak kajian tentang beliau dibahas ketika masih menjadi Walikota Pontianak.

Berdasarkan latar belakang masalah tersebut, penulis memunculkan rumusan masalah: Bagaimana proses penyusunan dan implementasi kebijakan Satu Data Kalbar di era Sutarmidji? Tulisan ini bertujuan untuk menjelaskan tahap penyusunan dan implementasi kebijakan Satu Data Kalbar pada masa pemerintahan Sutarmidji-Ria Norsan. Analisis akan dilihat dalam dua konsep, yaitu analisis kebijakan publik dan faktor pemimpin dalam pembuatan kebijakan. Konsep analisis kebijakan publik digunakan untuk memetakan alur penyusunan dan implementasi kebijakan Satu Data Kalbar. Sementara faktor pemimpin digunakan untuk mengidentifikasi peran Sutarmidji dalam kesuksesan kebijakan tersebut.

\section{METODOLOGI}

Pendekatan penelitian yang digunakan adalah pendekatan kualitatif dengan jenis penelitian deskriptif. Peneliti ingin mendalami proses hingga implementasi kebijakan Satu Data Kalbar melalui pendekatan individu sosok Sutarmidij sebagai salah satu faktor penentu.

Pengumpulan data menggunakan metode wawancara, pengamatan, studi literatur baik luring maupun daring. Wawancara dilakukan secara semi terstruktur dengan penentuan informan menggunakan metode purposive sampling. Informan yang diwawancarai adalah perwakilan Dinas Komunikasi dan Informatika Provinsi Kalimantan Barat. Tahap analisis data dilakukan melalui empat tahapan, yaitu seleksi data, verifikasi data, penyajian data, dan dilanjutkan dengan pengambilan kesimpulan berdasarkan panduan teori- teori (Marlian \& Sari, 2020). Lokasi penelitian adalah Provinsi Kalimantan Barat dengan memfokuskan pada aktifitas pengelola Satu Data Kalbar di Dinas Komunikasi dan Informatika Provinsi Kalimantan Barat, bertempat di Pontianak.

\section{HASIL DAN PEMBAHASAN}

\section{Penyusunan dan Implementasi Kebijakan Satu Data Kalimantan Barat}

Kebijakan Satu Data merupakan upaya Pemerintah melakukan perbaikan dan peningkatan kualitas tata kelola pemerintah dalam urusan data. Kebijakan ini berguna untuk tahap pengambilan keputusan dan sebagai bentuk pemenuhan data bagi masyarakat. Berdasarkan Perpres No.39 tahun 2019 terkait Kebijakan Satu Data, maka tiap-tiap daerah di Indonesia pun memiliki kewajiban untuk menerapkan kebijakan tersebut tak terkecuali Provinsi Kalimantan Barat. Terkait dengan Kebijakan Satu Data tersebut, maka Provinsi Kalimantan Barat melalui Pergub No.119 tahun 2019 mengeluarkan peraturan yang mengatur tentang Program Satu Data di Kalimantan Barat.

Satu Data memiliki prinsip yang terbagi atas tiga prinsip utama yaitu, satu standar data, satu metadata baku dan satu portal data. Dengan demikian, pemanfaatan data pemerintah tidak hanya terbatas pada penggunaan secara internal antar instansi, tetapi juga sebagai bentuk pemenuhan kebutuhan data publik bagi masyarakat (Kalbar Online, 2018). Tujuan dari Program Satu Data yang tertuang dalam Pergub tersebut merupakan penyelarasan dari visi dan misi Gubernur Kalimantan Barat yakni Bapak Sutarmidji. Visi beliau mengatakan bahwa "Terwujudnya Kesejahteraan Masyarakat Kalimantan Barat Melalui Percepatan Pembangunan Infrastruktur Dan Perbaikan Tata Kelola Pemerintahan". Misi-misi beliau juga terkait dengan pembangunan 
dan tata kelola pemerintahan di Kalimantan Barat (Pemerintah Provinsi Kalimantan Barat, 2019).

Penerapan Kebijakan Satu Data di Kalimantan Barat dilakukan melalui proses perumusan kebijakan, penetapan kebijakan, dan evaluasi kebijakan. Pertama, proses perumusan kebijakan terdiri atas latar belakang direncanakannya kebijakan tersebut dan dukungan baik dari eksekutif maupun legislatif serta permintaan dari pemerintah pusat. Kedua, penetapan kebijakan ditandai dengan adanya Peraturan Gubernur Nomor 119 Tahun 2019. Ketiga, evaluasi kebijakan dilakukan melalui koordinasi Dinas Kominfo sebagai leading sector. Gambar berikut memberikan penjelasan alur penerapan Kebijakan Satu Data di Kalimantan Barat.

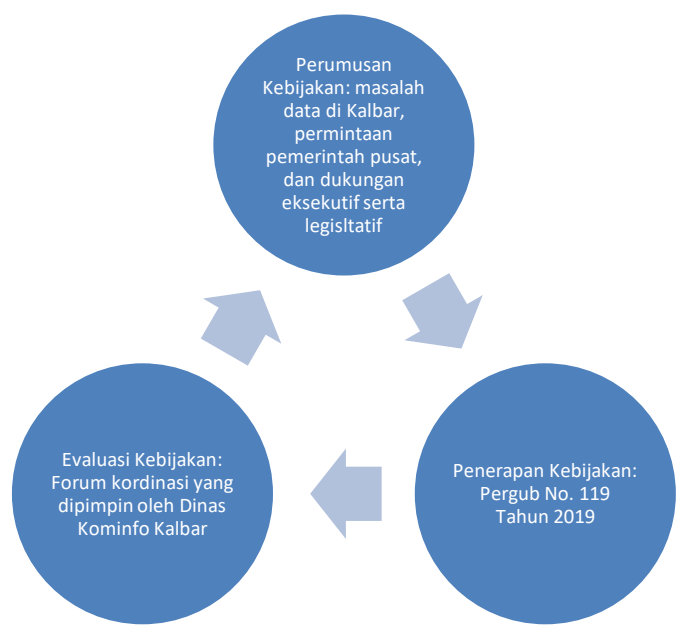

Gambar 1: Alur Penerapan Kebijakan Satu Data di Kalimantan Barat, Sumber: Penulis (2021)

Tahap pertama terdiri dari beberapa penjelasan yang mendukung munculnya kebijakan tersebut. Mulai dari permasalahan data di Kalimantan Barat yang masih buruk, keinginan dari pemerintah daerah, serta adanya permintaan dari pusat.

Wawancara kami terhadap Kepala Bidang Persandian dan Statistik Dinas Komunikasi dan Informatika Provinsi Kalimantan Barat pada tanggal 2 September 2020 di Kantor Diskominfo Provinsi Kalimantan Barat menunjukkan bahwa sebenarnya asal-usul mengenai
Kebijakan Satu Data Kalbar, yakni buruknya image mengenai data profil di pemerintahan yang tidak memuaskan dan kurang dapat diakses secara transparan. Selain itu, alasan data yang sulit untuk di dapatkan dan akurasi data yang didapatkan dipertanyakan validasinya (Erwanto, 2020).

Informan kami mengatakan jika kesulitan data yang dicari saat ini juga dikarenakan akibat data yang terpencar di mana-mana, sehingga menyulitkan untuk memproses dan mengolahnya menjadi data yang baku. Puncaknya saat Debat Pilpres yang lalu, saat para Capres sedang berdebat dengan mengeluarkan data, data tersebut seolah diserang dengan dipertanyakan kebenaran datanya, maka hal inilah yang mengakibatkan muncul pencetusan Program Satu Data tersebut. Namun, beliau mengatakan jika pengaturan data ini tidak secepat yang dipikirkan, karena menghimpun data-data yang terpencar bukanlah hal yang mudah. Beliau menganalogikan dengan negara Amerika Serikat yang membutuhkan waktu 10 tahun untuk dapat membenarkan dan menata data di negaranya, sementara Indonesia baru memulainya pada 2019 lalu.

Program Satu Data merupakan program pemerintah pusat yang diamanatkan juga kepada pemerintah daerah sebagai sarana publikasi mengenai data-data dan statistik yang bertujuan untuk membuat data yang akurat, mutakhir, terpadu, dapat dipertanggungjawabkan dan mudah diakses (Diskominfo Kalbar, 2020a). Program satu data ini mencakup seluruh aspek kehidupan yang masing-masing data dihimpun oleh instansi terkait. Program ini bertujuan untuk meminimalisir adanya kebingungan terhadap data yang disajikan, pada awalnya data dan statistik akan ditampilkan oleh masing-masing instansi terkait, akan tetapi dengan adanya program satu data di tingkat provinsi ini menjadikan Dinas Kominikasi dan Informatika Provinsi sebagai "wali data", menjadi pihak yang berwenang untuk mempublikasikan data dan statistik yang didapat dari instansi bidang terkait. 
Contoh sederhana, Dinas Lingkungan Hidup akan menghimpun data yang berkaitan dengan lingkungan hidup kemudian akan dikirimkan kepada Dinas Komunikasi dan Informatika sebagai "wali data" untuk dipublikasikan kepada masyarakat luas.

Menurut hasil wawancara, informan juga menyebutkan bahwa pihak eksekutif sangat berkepentingan karena selama ini terbangun image bahwa profil pemerintah yang dirilis dari masing-masing lembaga terkait bisa berbeda (Erwanto, 2020). Hal ini jelas memberikan dampak buruk bagi semangat e-government dan open government. Belum lagi bagi kalangan pebisnis maupun investor yang dapat kebingungan ketika membutuhkan data dari pemerintah Indonesia untuk keperluan membangun relasi bisnis dengan pemerintah. Para peneliti dan juga mahasiswa sering juga mengalami kendala yang sama ketika mengakses data terbitan dari pemerintah.

Selain didorong oleh aturan dari pemerintah pusat, kebijakan Satu Data Kalbar juga disebabkan oleh pengalaman ketersediaan data di Kalimantan Barat. Selama ini banyak perencanaanperencanaan program tidak didukung data yang akurat. Akibatnya perencanaan program tidak terimplementasi secara baik (Darsani, 2019). Menurut Sutarmidji satu program tidak akan berjalan secara baik dan tahan lama. Karena tidak didukung data yang akurat (Darsani, 2019). Beliau juga menegaskan dengan data yang terintegrasi dan terakselerasi dengan berbagai instansi pemerintah bisa meningkatkan program pemerintah daerah dengan baik (Darsani, 2019). Selain data yang terintegrasi dengan baik, Gubernur Kalimantan Barat menyebutkan bahwa data juga harus mudah diakses oleh semua masyarakat yang membutuhkan dan sesuai dengan aturan yang berlaku (Darsani, 2019)

Kebijakan Satu Data termasuk dalam salah satu keinginan besar Gubernur agar di akhir masa kepengurusan beliau, semua data di Kalbar sudah terintegrasi. Dinas Komunikasi dan Informatika pada prinsipnya mendukung komitmen tersebut. Sekarang ini mereka juga sedang gencar menyelesaikan masalah mengenai Kebijakan Satu Peta yang berkaitan dengan hutan lindung. Kendala data geospasial terletak pada plotting pemetaan. Ada data yang ketika plotting banyak yang sudah tidak ada lagi. Atau bahkan ketika diplotting ternyata overlapping dengan pemukiman penduduk, dengan area penggunaan lainnya, semisal area budidaya. Ke depan pemerintah daerah berkeinginan mewujudkan Kebijakan Satu Peta.

Berdasarkan data yang kami temukan, menunjukkan bahwa penyusunan kebijakan Satu Data Kalbar lebih banyak didominasi pengaruh dari eksekutif. Hal ini dilandasi pada kebutuhan Pemda atas data yang baik dan terintegrasi. Selain itu, pengaruh dari kebijakan pusat melalui Perpres 39 tahun 2019 menjadikan dorongan yang lebih kuat bagi Pemda untuk menerapkannya di tingkat pemerintahan daerah. Pada prinsipnya legislatif juga tidak memberikan penolakan mengingat hal ini akan mendukung peran maksimal pemerintah daerah dalam melayani masyarakat.

Pada tahap penerapan, kebijakan yang masih tergolong baru ini belum dapat bekerja secara maksimal. Menurut data yang dihimpun dari Dinas Komunikasi dan Informatika Provinsi Kalimantan Barat menunjukkan belum meratanya jumlah admin Satu Data di setiap instansi di Kalimantan Barat. Sebagai contoh tidak ada admin di Biro Kesejahteraan Rakyat Setda Provinsi Kalimantan Barat, sedangkan di Dinas Perhubungan Kalimantan Barat terdapat sebanyak 202 orang admin. Dengan perbedaan yang cukup banyak ini tentu menggambarkan belum meratanya penyebaran admin untuk mendukung agar program Satu Data ini dapat berjalan dengan baik. Program Satu Data di Kalimantan Barat hingga 22 Juli tahun 2020 berhasil mengumpulkan sebanyak 2,315 dataset (Diskominfo Kalbar, 2020a)

Berdasarkan wawancara, ditemukan bahwa Diskominfo memiliki peran yang 
penting sebagai operator penghimpun data dan juga walidata (Erwanto, 2020). Walidata yang dimaksud di sini adalah Diskominfo memiliki peran dalam koordinasi dan menjadi wadah penampungan data untuk kemudian menginstruksikan kepada lembaga atau aparatur daerah lainnya agar dapat dirapikan metadatanya. Di mana metadata adalah data mengenai data itu sendiri, sehingga dapat dikatakan jika metadata adalah data real dari data itu sendiri. Untuk saat ini, Program Satu Data ini tergolong berjalan dengan lancar, karena ditandai dengan sudah terhimpunnya ribuan data dari masing-masing lembaga pemerintahan yang telah masuk di portal Open Data Kalbar. Ke depannya, informan berharap jika Pemerintah dapat merangkul lembaga-lembaga non pemerintahan dan LSM untuk dapat terbuka mengenai data di berbagai daerah (Diskominfo Kalbar, 2020b).

Pergub Nomor 119 Tahun 2019 menjadi sebuah pedoman bagi pemerintah Daerah dalam mewujudkan satu data yang akurat, mutakhir, terpadu, dan dapat dipertanggungjawabkan, serta mudah diakses dan dibagipakaikan. Peraturan ini bertujuan untuk menyusun dan menyiapkan basis data dan pembangunan sesuai dengan tugas pokok dan fungsi masing-masing perangkat daerah; mewujudkan basis data pembangunan yang akurat, mutakhir, terpadu, dapat dipertanggungjawabkan, mudah diakses dan dibagipakaikan, serta dikelola secara seksama, terintegrasi, dan berkelanjutan; mendorong keterbukaan dan transparansi data sehingga tercipta perencanaan dan perumusan kebijakan pembangunan yang berbasis pada data; dan mewujudkan pelaksanaan, pengendalian, monitoring, evaluasi dan pelaporan pembangunan yang dapat dipertanggungjawabkan. Kebijakan Satu Data Kalbar diwujudkan pada laman data.kalbar.go.id. Portal ini baru diluncurkan pada 4 Maret 2019.

Gubernur berharap pasca diluncurkan portal satu data dapat memberikan akses seluas luasannya kepada masyarakat berkaitan dengan data yang dimiliki oleh pemerintah (Darsani, 2019). Adanya Portal
Satu Data ini dapat membantu Pemerintah Provinsi Kalbar dalam penyusunan perencanaan program pemerintah daerah dapat terimplementasi secara baik dan akurat di setiap program yang ada (Darsani, 2019). Penulis juga pada bagian selanjutnya akan memetakan personalitas gubernur sebagai faktor yang sangat berperan dalam diwujudkannya kebijakan tersebut.

Informan kami menjelaskan bahwa runutan penerapan kebijakan ini berkaitan juga dengan Perpres Nomor 95 Tahun 2018 mengenai SPBE (Sistem Pemerintahan Berbasis Elektronik). Gubernur juga memiliki visi dan misi yang sesuai dengan prinsip tata kelola pemerintahan yang lebih baik. Ketiganya dikemas oleh pemerintah Provinsi Kalimantan Barat dengan penyajian datadata digital. Memang diakui oleh informan bahwa penerapan kebijakan satu data ini belum semaksimal yang dilaksanakan di negara maju, seperti Amerika Serikat. Sebagai contoh di Amerika Serikat akses informasi sudah realtime sepersekian detik. Pengembangan sistem satu datanya bahkan sudah dikembangkan puluhan tahun. Sementara di Kalbar dan Indonesia baru benar-benar memiliki landasan hukum sejak 2019. Pada prinsipnya penerapan Kebijakan Satu Data Kalbar bersifat terbuka dan transparan. Pada portal yang disajikan menampilkan semua urusan statistik sektoral di lingkungan Pemerintah Provinsi Kalimantan Barat termasuk juga data pendukung dan data informasi yang dibutuhkan oleh publik. Tahapan teknis pemasukan data harus memenuhi persyaratan, yaitu mempunyai standar data dan mempunyai meta data.

Setelah implementasi kebijakan, tahap selanjutnya yang juga penting adalah dilakukannya monitoring. Pada contoh kasus implementasi Kebijakan Satu Data Kalbar dalam pengelolaan Heart of Borneo di Kabupaten Sintang, pola monitoring dilakukan berjenjang pada setiap segmen isu. Baik monitoring pada sistem Satu Data Kalbar dan pada pengelolaan HoB di Taman Nasional Bukit Raya Sintang. Kegiatan pengawasan Satu 
Data Kalbar dilakukan melalui kegiatan seperti rakor dan beberapa workshop. Workshop dilakukan kepada pelaku teknis di masing-masing SKPD untuk mampu menginput data dan mengevaluasi proses penginputan data. Sementara kegiatan rakor dilaksanakan menjelang diadakannya Forum Satu Data Tingkat Provinsi Kalimantan Barat.

Pada tahun 2020, pernah dilaksanakan kegiatan lanjutan Persiapan Forum Satu Data Indonesia Tingkat Provinsi Kalimantan Barat Tahun 2020, bertempat di ruang rapat Bappeda Lantai 1 Bappeda Prov. Kalbar (Bappeda Kalbar, 2020). Kegiatan rakor dipimpin langsung oleh Kabid PPEP (Drs. Liwono, M.Si) serta dihadiri oleh BPS dan Diskominfo Prov. Kalbar. Pertemuan tersebut membahas tentang Draft Keputusan Gubernur tentang Pembentukan Tim Koordinasi Forum Satu Data Indonesia dan Tim Sekretariat Forum Satu Data Indonesia Tingkat Provinsi Kalimantan Barat Tahun 2020, Mekanisme Pelaksanaan Forum Satu Data Indonesia serta Walidata Pendukung di Tingkat Perangkat Daerah (Bappeda Kalbar, 2020).

Hasil temuan kami juga menunjukkan bahwa pemerintah Provinsi Kalbar masih melakukan evaluasi dengan memutahirkan data agar tidak ada lagi terjadinya data yang berbeda. Untuk itu peran Satu Data ini sangat penting dilakukan guna menyelaraskan data yang ada di Provinsi Kalbar. Hal ini dikemukakan oleh Wakil Gubernur Kalbar, Ria Norsan, selama ini di Kalbar berkutat masalah data yang selisih dan data yang berbeda, sehingga dengan dikeluarkan kebijakan gubernur pada bulan Maret tahun 2019 yang lalu untuk mengkodinir supaya Kalbar memiliki satu data sehingga data yang kita gunakan itu akuntabel dan solid (Bappeda Kalbar, 2020)

Harapannya kebijakan dari provinsi hingga ke tingkat daerah itu sama dan memiliki perencanaan yang matang sehingga bisa mencapai suatu target yang diinginkan agar membangun Kalbar lebih maju (Bappeda Kalbar, 2020). Selain data statistik dikenal pula data berbasis keruangan atau geospasial yaitu semua data dan informasi yang menyangkut lokasi dan keberadaan suatu objek. Wagub menjelaskan pada sektor pertanian, jika memanfaatkan data geospasial maka akan tergambar secara nyata lokasi serta luas lahan pertanian sehingga potensi-potensi di sektor pertanian akan tercatat secara akurat (Bappeda Kalbar, 2020). Gubernur juga menekankan dalam website Satu Data Kalbar bahwa Data adalah kunci keberhasilan pengambilan keputusan untuk Kalbar baru yang lebih baik.

Selain itu, sistem monitoring juga dapat dilakukan melalui portal yang telah dibangun. Diskominfo selaku kordinator data (wali data) dapat melakukan pemeriksaan dinas atau OPD mana saja yang belum menyampaikan data. Rekap ini disampaikan pada rapat evaluasi dengan menyusun daftar urutan data terbanyak hingga paling sedikit.

Proses rapat evaluasi juga dilakukan secara berkala. Informan mengakui pola koordinasi di era digital sudah sangat mudah karena kemajuan teknologi. Tahapannya dengan menyurati tiap dinas terkait, tetapi bukan instansi vertikal, Lalu, akan dimintakan admin data tiap dinas berdasarkan SK dari masing masing kepala dinas. Setelah itu tim dari Diskominfo Kalbar akan membuat grup whatsapp. Pola komunikasi via whatsapp ini dirasa efektif untuk meningkatkan kordinasi serta efektif dan efisien. Di samping itu, para admin ini juga memiliki email khusus untuk berkordinasi. Sebelum era pandemi, rapat kordinasi dan evaluasi dilakukan secara tatap muka. Namun, sejak diterapkannya Bekerja Dari Rumah, kegiatan rapat kordinasi berkala dilakukan secara virtual. Pola ini sejalan dengan instruksi presiden untuk menjalankan pemerintahan secara digital.

\section{Faktor Kepemimpinan Pada Implementasi Kebijakan Satu Data Kalimantan Barat}

Pada kasus ini, peran Sutarmidji selaku kepala daerah di Kalimantan Barat juga memegang peran penting. Beberapa analisa terkait faktor kepemimpinan akan 
dibahas ke dalam beberapa subpembahasan, yaitu: karakter pribadi, faktor lingkungan sosial politik di Kalimantan Barat, faktor lingkungan terdekat, dan kepribadian pribadi.

Sutarmidji merupakan sosok yang menarik dalam peta perpolitikan di Kalimantan Barat. Jika menelusuri karir politik beliau, praktis sejak 1997-sekarang beliau selalu menduduki posisi baik di legislatif dan eksekutif tanpa memiliki jeda. Mulai dari anggota DPRD Kota Pontianak 1997-1999 dan 1999-2003, Wakil Walikota 2003-2008, Walikota Pontianak dua periode 2008-2013 dan 2013-2018, dan sekarang Gubernur Kalimantan Barat untuk periode 20182023.

Karir politik beliau dimulai dengan bergabung ke Partai Persatuan Pembangunan (PPP) atas ajakan dari Ali Akbar, sepupunya yang juga politikus PPP (Fatria, 2018) Pada Pemilu 1999, ia dipercaya sebagai anggota DPRD Kota Pontianak, kemudian pada tahun 2003, ia terpilih sebagai Wakil Walikota Pontianak mendampingi Buchary Abdurrachman (Fatria, 2018). Pada Pilkada 2008, Sutarmidji bersama Paryadi terpilih menjadi Walikota dan Wakil Walikota Pontianak, periode 2008-2013 (Fatria, 2018). Kemudian pada tahun 2013, Sutarmidji berpasangan dengan Edi Rusdi Kamtono kembali terpilih menjadi Walikota dan Wakil Walikota Pontianak periode 2013-2018 (Fatria, 2018). Pada 2018 beliau bersama H. Ria Norsan dilantik menjadi Gubernur dan Wakil Gubernur Kalimantan Barat (Fatria, 2018).

Secara karakter beliau terkenal dengan sikap tegas yang membuat banyak orang segan, bahkan tidak sedikit yang takut. Beliau tidak ragu untuk melakukan pemindahan pegawai atau bahkan kepala dinas jika merasa tidak dapat melaksanakan tugas dengan baik. Tercatat pada 2020 ini Kadishub dirotasi pasca insiden beberapa penumpang pesawat positif Covid-19 bisa masuk ke Kota Pontianak. Pada awal masa jabatan beliau melakukan evaluasi atas jajaran kepala dinas dan perangkatnya yang tidak sesuai dengan kualifikasi. Bahkan tercatat di berbagai media, Sutarmidji sangat sering mengeluarkan pernyataan "akan mencopot jika..." dan ultimatum kepada dinas-dinas yang menurut beliau bermasalah. Bahkan pada tahun 2019 beliau menantang kepalakepala dinas untuk dapat mencapai zona hijau pelayanan dari Ombudsman dalam waktu setahu. Jika tidak tercapai, maka jabatan mereka akan dicopot.

Sutarmidji juga terkenal tidak sungkan untuk memarahi kepala dinas dan ASN lain di depan media atau saat rapat. Namun, diakui oleh beliau dalam beberapa pemberitaan media bahwa teguran dilakukan berdasarkan pada data. Bahkan beliau juga sering menantang orang orang yang tidak setuju dengan kebijakannya untuk berdebat tapi dengan membawa data yang valid. Menurut penuturan para wartawan yang pernah mewawancarai beliau, Sutarmidji sangat menguasai aturan hukum. Sehingga beliau sangat paham betul tindakan yang dilakukan sudah sesuai di koridor aturan hukum.

Di samping kebiasaan memarahi tersebut, beliau juga sangat adil untuk memberikan apresiasi bagi ASN atau dinas yang berhasil mencapai target atau memiliki prestasi. Misalnya ketika di Kalbar meningkat drastis jumlah desa mandiri, beliau tidak sungkan memberikan pujian kepada desa terkait dan juga dinas pembangunan desa dan masyarakat. Karakter pribadi tersebut juga konsisten beliau terapkan sejak menjabat menjadi Walikota Pontianak. Pengalaman sukses di Kota Pontianak beliau coba tularkan ke Pemda Provinsi Kalimantan Barat. Selama menjabat sebagai walikota, beliau juga terkenal tidak sungkan menerapkan pola ketegasan tersebut sehingga membangun kesan beliau orang yang menyeramkan. ASN Pemkot sangat merasakan ketegasan dan kedisiplinan beliau. Sehingga dalam beberapa kali pengamatan pada saat menjelang beliau dilantik, para ASN pemprov mulai bersiap-siap untuk menghadapi perbedaan karakter pimpinan.

Namun, hasil yang dicapai juga signifikan. Terbukti beliau dipercaya rakyat menjabat walikot selama dua periode. Beberapa bidang yang sangat menonjol selama kepemimpinan beliau 
adalah bidang infrastruktur jalan, pendidikan dan pelayanan kesehatan yang menerapkan sistem rumah sakit tanpa kelas, pembangunan dan penataan tamantaman publik seperti Taman Alun-alun Kapuas dan Taman Digulis Untan Pontianak (Antaranews, 2018).

Sutarmidji menerapkan pelayanan satu atap dalam mengurus perizinan demi mempercepat pelayanan. Beliau melakukan pemangkasan perizinan menjadi 14 jenis saja dari jumlah 99 jenis. Pada masa kepemimpinannya, isu transparansi bantuan sosial menjadi hal wajib dan terinformasi melalui koran maupun situs Pemkot Pontianak (Antaranews, 2018). Pada bidang keuangan, sejak tahun 2011 Pemerintah Kota Pontianak mendapatkan selalu mendapat predikat WTP dari BPK. Prestasi berlanjut pada tahun 2015 dengan anugerah predikat pelayanan publik terbaik se-Indonesia oleh ORI. Pemkot Pontianak bahkan menjadi acuan tata kelola yang baik dalam pelayanan pada publik, seperti standar layanan publik terbaik, inovasi terbaik, pelayanan perizinan tercepat, efisiensi dan efektivitas anggaran dan lainnya bagi beberapa Pemda yang ada di Indonesia (Antaranews, 2018).

Pengalaman beliau selama dua periode di Kota Pontianak dicoba direplikasi di tingkat provinsi. Melalui visi dan misinya, beliau ingin mewujudkan Kalbar baru yang lebih maju dan lebih sejahtera. Poin pertama yang dilakukan adalah melakukan reformasi tata kelola pemerintahan, persis seperti yang sudah diterapkan ketika memimpin Kota Pontianak (Antaranews, 2018). Kedua, beliau juga berkomitmen akan membangun dan meningkatkan sekitar $300 \mathrm{~km}$ jalan di Kalbar dalam tiga sampai empat tahun sudah bisa diselesaikan (Antaranews, 2018). Ketiga, percepatan pembangunan, mulai dari infrastruktur jalan, bidang pendidikan, dan kesehatan, seperti yang saat ini sudah dirasakan oleh masyarakat Kota Pontianak (Antaranews, 2018). Percepatan pembangunan tersebut berazaskan keadilan, sehingga semua kabupaten/kota harus mendapatkan perhatian, dengan tidak memandang suku, agama dan golongan, katanya.

Keempat, pemerintahan beliau juga memfokuskan peningkatan IPM yang di masa awal jabatan beliau berada di peringkat 29 dari 33 provinsi (Antaranews, 2018). Kelima, peningkatan pelayanan publik dan meningkatkan nilai tukar petani. Beliau meyakini bahwa dengan membangun jalan-jalan yang menghubungkan desa-desa hingga tingkat kecamatan, kabupaten/kota hingga tingkat ibukota provinsi yakni Kota Pontianak, sehingga para petani bisa dengan mudah memasarkan hasil pertaniannya (Antaranews, 2018). Pola pembangunan beliau sejalan dengan gaya membangun yang dilakukan Presiden Jokowi. Hal ini juga mendapatkan kesan tersendiri di mata presiden.

Keenam, berdasarkan pengalaman beliau dalam manajemen RS Kota Pontianak, maka beliau juga akan meningkatkan bangunan RS Soedarso menjadi 12 lantai, dan menerapkan layanan tanpa kelas yang diprioritaskan untuk pemegang kartu BPJS dengan ruangan sendiri dengan standar pelayanan seperti kelas satu (Antaranews, 2018). Pembangunan RS Soedarso ini sudah dimulai pada tahun 2019 .

Prestasi lain yang pernah beliau dapatkan selama memimpin Kota Pontianak adalah dengan meraih penghargaan kategori sangat baik bagi Dinas Penanaman Modal dan Pelayanan Terpadu Satu Pintu (DPMPTSP), Dinas Kependudukan dan Pencatatan Sipil (Disdukcapil) serta RSUD Kota Pontianak (Hasan, 2018). Beliau juga mendapatkan penghargaan sebagai role model penyelenggaraan pelayanan publik kategori baik dan sangat baik ini diberikan berdasarkan hasil evaluasi terhadap 72 Kabupaten-Kota Role Model sesuai dengan KepmenPANRB Nomor 21 Tahun 2017 tentang penetapan Provinsi, Kabupaten/Kota, Kementerian/Lembaga dan unit penyelenggaraan pelayanan publik sebagai Lokasi penyelenggaraan evaluasi pelayanan publik tahun 2017 (Hasan, 2018).

Faktor lain yang juga mempengaruhi 
aspek kepemimpinan beliau adalah sistem politik, budaya dan juga pemberitaan media massa. Sistem politik yang mengedepankan pada pemilihan umum memungkinkan tiap warga masyarakat memberikan hak suaranya kepada calon kepala daerah. Meskipun secara keikutsertaan pada partai, Sutarmidji tidak berasal dari partai besar, tetapi kepuasan rakyat atas hasil pembangunan beliau menjadi modal penting dalam pemilu. Bahkan ketika beliau maju pada periode kedua di Kota Pontianak, sempat ada guyonan "dipasangkan dengan sendal jepit pun Sutarmidji tetap akan menjadi walikota”. Hal ini menunjukkan bahwa sosok beliau didukung dengan kepercayaan warga menjadi pendukung bagi sepak terjang beliau selama menjadi pemimpin. Orientasi kepemimpinan beliau adalah melayani rakyat bukan partai.

Secara budaya beliau berasal dari suku Melayu yang merupakan suku dominan di Kota Pontianak. Termasuk juga tiga suku dominan di Kalbar. Membuat beliau sebagai representasi dari orang Melayu menjadi kental. Walaupun secara sub-suku Melayu beliau sering digelar orang Tambi, tetapi ketika dihadapkan pada pilihan suku lain di Kalbar seperti yang terjadi pada Pilkada 2018, orang-orang Melayu memberikan suaranya kepada beliau. Meskipun faktor kesukuan ini tidak menjadi faktor utama, mengingat beliau juga dapat unggul suara di daerah mayoritas Dayak. Menjadi Melayu tetap saja memberikan nilai plus bagi beliau.

Selain itu, identitas keislaman beliau juga menjadi faktor yang ikut mempengaruhi. Sudah menjadi rahasia umum bahwa di Indonesia secara umum, menjadi calon pemimpin berasal dari golongan Islam akan menjadi nilai plus. Di Kalbar apalagi dengan tambahan identitas Melayu menjadikan sosok Sutarmidji jelas menjadi pilihan yang baik. Sebagian masyarakat Kalbar sudah merasakan dipimpin oleh kepala daerah berasal dari Suku Dayak selama dua periode dan merasakan kurang puas. Bahkan hal ini juga dinyatakan oleh sesama Suku Dayak mengingat Gubernur sebelumnya secara sub-suku tidak disenangi oleh sub-suku Dayak lainnya. Bahkan dalam pemilihan kepala OPD cenderung memilih lingkaran terdekatnya saja. Kondisi psikologis ini menjadi momentum yang baik bagi seorang Sutarmidji dengan prestasi pembangunan dua periode di Kota Pontianak.

Faktor media lokal juga ikut mempengaruhi gaya kepemimpinan beliau. Sutarmidji dikenal tidak senang dengan pencitraan. Sehingga hanya akan muncul di media ketika beliau merasa perlu dan hanya segelintir media saja. Mengingat beliau sangat tinggi dalam meletakkan standar bagi pewawancara. Menurut beberapa wartawan, beliau tidak sungkan menegur wartawan yang menanyakan halhal yang bisa dibaca di website Pemda. Selain secara pribadi, sosok beliau sering menjadi sorotan media lokal. Baik lewat prestasi-prestasi yang ditorehkan oleh Pemkot Pontianak, maupun pernyataanpernyataan beliau seputar pemerintahan atau kontroversi kebijakannya. Sangat jarang beliau diberitakan secara negatif atau bahkan kehidupan pribadi yang terekspos. Sehingga tampak jelas secara pemberitaan beliau juga diuntungkan dan tidak jarang beliau menggunakan media sebagai sarana meningkatkan kepercayaan publik lewat pernyataan-pernyataan beliau.

Karakter pribadi beliau juga dapat ditelusuri melalui pengalaman pribadi beliau semasa kecil dan kondisi keluarga yang ikut mendorong pencapaian beliau saat ini. Masa kecil Sutarmidji pernah dihabiskan dengan menjual koran di lingkungan Kantor Wali Kota Pontianak (Antaranews, 2018).

Pada masa kecil, Sutarmidji terbiasa menjual koran di sekitar kawasan kantor Bea Cukai Pontianak, Pelabuhan Dwikora, dan sekitar Kota Pontianak dari sejak usia kelas 2 SD hingga dapat mengantarkan beliau menyelesaikan pendidikan sarjana di Fakultas Hukum, Universitas Tanjungpura Pontianak, Kalbar (Antaranews, 2018). Pengalaman berjuang sejak kecil ini menurut kami menjadi salah satu pengalaman yang membentuk karakter dan juga visi beliau atas pelayanan berbasis rakyat. Beliau ikut 
mengamati masyarakat sejak kecil dan mengetahui kondisi masyarakat Pontianak dari pengalaman tersebut.

Pengalaman masa kecil lain juga sering beliau ceritakan kepada media atau saat kegiatan-kegiatan seputar pengalaman karir politik beliau adalah ketika berjualan koran pernah ditanya seorang pejabat pemkot. Beliau ditanya oleh Ir Pedi Natasuwarna yang dulu Kepala Dinas Pekerjaan Umum. Pertanyaan adalah "Nanti besar cita-citanya jadi apa?" Beliau menjawab ingin menjadi walikota (Antaranews, 2018). Ternyata jawaban itu menjadi pemicu sekaligus niat dan doa yang dikabulkan di kemudian hari.

Di samping faktor pengalaman masa kecil, faktor keluarga juga ikut mempengaruhi. Setidaknya dua kondisi dari keluarga Sutarmidji yang patut diperhatikan. Pertama, beliau berasal dari keluarga tidak kaya. Kedua, ayah beliau pernah aktif di partai politik. Sutarmidji lahir di Pontianak, 29 November 1962, yang merupakan anak keenam dari sembilan bersaudara yang lahir dari pasangan Tahir Abubakar dan Djaedah (Antaranews, 2018). Ayahnya hanya seorang pegawai biasa di Departemen Agama di Pontianak dan pernah aktif di Partai Masyumi (Antaranews, 2018).

\section{Kendala Implementasi Kebijakan Satu Data Kalbar}

Sesuai teorinya, implementasi kebijakan merupakan salah satu tahapan dalam proses kebijakan publik dan sekaligus merupakan aspek yang krusial dari keseluruhan proses kebijakan. Aspek kesiapan dan perencanaan menjadi penting. Dari temuan kami menunjukkan bahwa gebrakan Satu Data Kalbar tidak serta merta ada. Tapi, didahului oleh beberapa faktor penentu. Mulai dari kebijakan di tingkat nasional, masalahmasalah kesimpangsiuran data di Kalbar, serta keinginan dari kepala daerah terpilih untuk menyusun skema satu data yang terintegrasi.

Pendapat lain yang kami kutip pada bagian tinjauan pustaka juga menekankan pada pentingnya penyediaan sarana untuk melaksanakan sesuatu kebijakan dan dapat menimbulkan dampak atau akibat terhadap sesuatu. Hasil penelitian kami menunjukkan bahwa Pemerintah Provinsi Kalimantan Barat sudah melakukan upaya persiapan dengan leading sector utama adalah Dinas Kominfo Kalimantan Barat. Selain karena amanat dari UU, dinas tersebut merupakan yang paling tepat dalam urusan penyediaan infrastruktur teknologi informatika. Telah disediakannya website Satu Data Kalbar menunjukkan bahwa Pemda Kalbar benarbenar serius dalam menerapkan kebijakan Satu Data Kalbar yang tertuang dalam Pergub Nomor 119 Tahun 2019.

Berdasarkan pendapat beberapa ahli yang kami kutip dan sajikan dalam bagian tinjauan pustaka, konsep implementasi diarahkan pada upaya pengejawantahan kebijakan yang dituangkan melalui produk hukum. Tahapan implementasi yang dilakukan oleh Pemda Kalbar adalah dengan persiapan infrastruktur, melakukan koordinasi, dan dilanjutkan dengan eksekusi poin-poin Pergub Nomor 119 Tahun 2019.

Tiga aktivitas implementasi kebijakan agar lebih operasional dapat dilakukan melalui tahap pengorganisasian, tahap interpretasi dan tahap aplikasi. Pemda Kalimantan Barat dalam menerapkan Pergub Nomor 119 Tahun 2019 sudah melalui beberapa tahapan tersebut.

Meski demikian, hasil penelitian kami menunjukkan bahwa masih terdapat kendala. Pertama, durasi waktu pelaksanaan Pergub masih sangat singkat. Perlu waktu lebih untuk benar-benar memastikan bahwa implementasi berjalan sesuai dengan tujuan akhir yang diinginkan. Hal ini didukung dengan belum terintegrasinya semua unit yang ada di Kalimantan Barat. Hasil penelitian kami menunjukkan bahwa sementara ini baru OPD yang berada dalam Pemerintah Provinsi Kalimantan Barat sudah berkoordinasi dan terintegrasi. Perpanjangan dinas di tiap kabupaten/kota masih diupayakan mengingat masingmasing berada pada kewenangan Bupati/Walikota. 
Kedua, sosialisasi kebijakan di masyarakat. Di tengah masyarakat yang begitu cepat terpapar efek media sosial, maka platform website menjadi suatu hal yang perlu ditingkatkan. Masyarakat saat ini lebih senang menggunakan instagram, facebook, dan whatsapp. Sehingga jika yang juga disasar adalah masyarakat umum, maka perlu ada penyesuaian dalam hal cara penyajian informasi. Meskipun kami menemukan terdapat akun instagram Open Data Kalbar, tetapi informasi di dalam akun tersebut menurut kami tidak semaksimal yang disajikan di website. Bahkan kami pernah menguji admin akun dengan menghubungi via pesan pribadi, tetapi tidak ditanggapi. Hal ini dapat menjadi kendala dalam aspek keterbukaan informasi publik dan kecepatan informasi.

Ketiga, pemerintah daerah dan pusat selama ini seperti kesulitan membendung efek negatif dari kecepatan informasi yang beredar di media sosial, khususnya hoax. Pemerintah seolah hanya menunggu saja jika terdapat informasi yang keliru untuk diklarifikasi atau dijatuhkan (take down). Tetapi, belum ada usaha yang masif untuk kemudian juga menggunakan media sosial untuk dapat mengadu kebenaran di cepatnya arus informasi. Hal ini terkait dengan tahap sosialisasi informasi kebijakan Satu Data Kalbar. Ketika masyarakat umum merasa sudah cukup puas dengan informasi di medsos, mereka akan menjadi enggan untuk menelusuri website.

Bahkan selain website Satu Data Kalbar, pemerintah daerah sudah memiliki website PPID Kalbar. Tujuan dari kedua website ini sama-sama menyajikan informasi kepada publik. Namun, pengamatan peneliti di lingkungan akademisi dan mahasiswa ditemukan bahwa kedua platform data ini masih belum digemari oleh para peneliti dan juga mahasiswa di Kalbar. Kebanyakan masih mengandalkan data yang didapatkan dengan mengunjungi dinas/instansi terkait.

\section{KESIMPULAN}

Implementasi Kebijakan Satu Data
Kalimantan Barat dilandaskan pada diterbitkannya Peraturan Gubernur no 119 tahun 2019. Penerapan dilakukan secara top down diawali dengan proses perumusan kebijakan, penetapan kebijakan, dan evaluasi kebijakan. Temuan kami menunjukkan bahwa peran Gubernur selaku kepala daerah sangat maksimal. Meski demikian pada prakteknya, pelaksanaan penghimpunan data dalam Satu Data Kalimantan Barat masih mengalami kendala karena mengandalkan dinas-dinas terkait untuk proaktif mengirimkan data. Koordinasi antar lembaga belum berjalan dengan baik.

Menindaklanjuti hasil penelitian ini, kami bermaksud memberikan beberapa rekomendasi terhadap pembuat kebijakan yang ada di Indonesia. Pertama, perlu ditingkatkan koordinasi dan komitmen dalam mewujudkan transparansi data yang terintegrasi antar daerah hingga skala nasional. Kedua, pemerintah pusat juga dapat menggandeng pemerintah provinsi yang sudah memiliki inovasi di bidang satu data agar kebijakan-kebijakan yang akan dihasilkan atau sedang dilaksanakan berbasis data. Ketiga, mendorong pihak terkait untuk dapat meningkatkan perhatian masyarakat atas ketersediaan informasi publik yang terbuka dan transparan sehingga mereka dapat ikut serta berpartisipasi dalam pembangunan di suatu daerah. Keempat, bagi peneliti selanjutnya agar dapat meneliti terkait kerja sama antara pusat dan daerah dalam mewujudkan Satu Data Indonesia berdasarkan best practice di beberapa daerah. Kelima, penelitian lapangan dengan tingkat mobilitas yang tinggi sangat sulit dilakukan di masa pandemi sehingga membutuhkan antisipasi penelitian literatur.

\section{UCAPAN TERIMA KASIH}

Penulis mengucapkan terima kasih kepada Fakultas Ilmu Sosial dan Ilmu Politik yang sudah berkenan mendanai kegiatan penelitian kami. Tidak lupa kami ucapkan kepada keluarga yang 
mendukung selalu kegiatan kami. Serta ucapan terima kasih terkhusus kami sampaikan kepada penulis kedua, Bapak Almarhum Sugito, yang selama proses penelitian senantiasa membimbing dan mengarahkan kami. Namun, menjelang penyelesaian penelitian beliau terlebih dahulu dipanggil oleh Allah SWT. Semoga tulisan ini menjadi amal jariyah bagi beliau.

\section{DAFTAR PUSTAKA}

Antaranews. (2018, June 29). Sutarmidji: Mantan Penjual Koran Bakal Jadi Gubernur Kalbar. Antaranews.

https://www.antaranews.com/berita/7 223 92/sutarmidji-mantan-penjualkoran bakal-jadi-gubernur-kalbar

Ayuningtyas, D. (2018). Kotak Hitam Sistem Penetapan Kebijakan dan Faktor-Faktor yang Mempengaruhinya. Jurnal Manajemen Pelayanan Kesehatan, 11(2), 44-48.

\section{Bappeda}

Kalbar.

(2020).

Lanjutan Persiapan Forum Satu

Data Indonesia Tingkat

Provinsi Kalimantan Barat Tahun 2020. Bappeda Kalbar. https://bappeda.kalbarprov.go.id/lanj utan persiapan-forum-satu-dataindonesia tingkat-provinsikalimantan-barat-tahun 2020/

Daraba, D. (2015). Faktor-Faktor yang Mempengaruhi Keberhasilan Program Pemberdayaan Masyarakat Miskin Di Kecamatan Polongbangkeng Utara Kabupaten Takalar Propinsi Sulawesi Selatan. Sosiohumaniora, 17(2), 168-169.

Darsani, H. (2019, March 4). Sutarmidji Resmi Luncurkan Portal Satu Data Kalbar. Tribun Pontianak. https://pontianak.tribunnews.com/20 19/03/04/sutarmidji-resmi-

luncurkan-portal satu-data-kalbar

Dedi, A., \& Sudarmo, U. R. (2019). Implementasi Kualitas Kebijakan Publik Dalam Perda Kabupaten Ciamis Nomor 10 Tahun 2012 Tentang Ketertiban, Kebersihan, Dan Keindahan. Journal of Management Review, 1-8.

Diskominfo Kalbar. (2020a). Tugas dan Fungsi. Diskominfo Kalbar. diskominfo.kalbarprov.go.id/index.p $\mathrm{hp} /$ pr ofil/tugas-dan-fungsi/

Diskominfo Kalbar. (2020b). Visi Misi. Diskominfo Kalbar. diskominfo.kalbarprov.go.id/index.p $\mathrm{hp} / \mathrm{pr}$ ofil/visi-dan-misi/

Erwanto, T. (2020). Satu Data Kalbar (Hasil Wawancara).

Fahturrahman, M. (2016). Faktor Birokrasi Dalam Keberhasilan Implementasi Kebijakan Publik. Tarbawi, 2(2), 14-27.

Fatria, J. (2018). Mantan Loper Koran Bakal Jadi Orang Nomor Satu di Kalbar. Kalbar Online. https://www.kalbaronline.com/2018/ 07/0 1/mantan-loper-koran-bakaljadi-orang nomor-satu-di-kalbar/

Febriantin, K. (2016). Faktor Pemimpin Dan Kepemimpinan Dalam Tata Kelola Pemerintahan Di Kabupaten Purwakarta Periode Tahun 2008-2015. Jurnal Politikom Indonesiana, 1(2), 43-58.

Hasan, S. (2018, January 29). Sutarmidji dengan Segudang Prestasi Membangun Pontiana. Obsession News.

https://www.obsessionnews.com/suta rmidji-dengan-segudang-prestasimembangun-pontianak/

Kalbar Online. (2018, December 3). Kerja dan Membangun Kalbar Dengan 
Data. Kalbar Online. https://www.kalbaronline.com/2018/ 12/0 3/kick-off-satu-data-kalimantanbarat/

Marlian, S., \& Sari, D. S. (2020). Implementasi Kebijakan Sabilulungan Sistem Penilaian Kinerja Pegawai (Sasikap) Di Lingkungan Pemerintah Kabupaten Bandung. Jurnal Administrasi Dan Kebijakan Publik, 5(2), 208-227.

Nazmi. (2018). Implementasi Kebijakan Pengembangan Industri Alat Kesehatan Dalam Negeri. Jurnal Kebijakan Kesehatan Indonesia: JKKI, 7(1), 42-48.

Parameswari, P., Legionosuko, T., \& Prasetyo, T. B. (2019). Analisis Kebijakan Peraturan Pemerintah Pengganti Undangundang Nomor 2 Tahun 2017 Tentang Organisasi Kemasyarakatan Dalam Perspektif
Peperangan Asimetris (Studi Kasus: Hizbut Tahrir Indonesia). Jurnal Peperangan Asimetris, 5(1), 1-18.

Pemerintah Provinsi Kalimantan Barat. (2019). Visi Misi. Pemerintah Provinsi Kalimantan Barat. https://kalbarprov.go.id/page/visi misi

Raharjo, E. H. B. (2018). Implementasi CMS Joomla dan Model RAD pada Pusat Transformasi Kebijakan Publik Indonesia. PROSIDING SISFOTEK (Sistem Informasi Dan Teknologi), 74-79.

Wardi, S. (2020). Gaya Kepemimpinan Walikota untuk Meningkatkan Kinerja dan Akhlak Aparatur Sipil Negara di Kota Pontianak. Jurnal Kajian Pembelajaran Dan Keilmuan, 3(2), 185-192. 
Bidang Ilmu Pengetahuan Sosial 